\title{
Host-Parasite relationships and co-infection of nasal mites of Chrysomus ruficapillus (Passeriformes: Icteridae) in southern Brazil
}

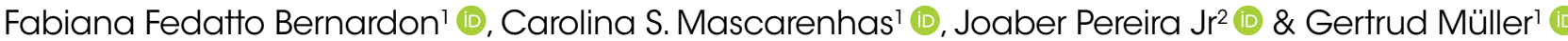 \\ 1. Laboratório de Parasitologia de Animais Silvestres (LAPASIL), Departamento de Microbiologia e Parasitologia, Instituto de Biologia, Universidade Federal de Pelotas, \\ Caixa Postal 354, 96010-900, Pelotas, RS, Brazil. (fabifedatto@gmail.com) \\ 2. Laboratório de Biologia de Parasitos de Organismos Aquáticos (LABPOA), Instituto de Oceanografia, Universidade Federal do Rio Grande, Caixa Postal 474 , \\ 96650-900 Rio Grande, Rio Grande do Sul, Brazil
}

Received 14 December 2017

Accepted 8 May 2018

Published 21 June 2018

DOI: 10.1590/1678-4766e2018025

\begin{abstract}
One hundred twenty-two Chrysomus ruficapillus were examined in southern Brazil, in order to research the presence of nasal mites and the parasite-host relationships. Nasal mite infections were analyzed for: presence of Ereynetidae and Rhinonyssidae considering the total number of hosts examined; Sexual maturity of males (juveniles and adults); Periods of bird collection and presence of co-infections. Were identified five taxa, four belongs to Rhinonyssidae (Sternostoma strandtmanni, Ptilonyssus sairae, P. icteridius and Ptilonyssus sp.) and one to Ereynetidae (Boydaia agelaii). Adult males were parasitized for one taxa more than juvenile males. Co-infections occurred in 22 hosts, between two, three and four taxa, belonging to Ereynetidae and Rhinonyssidae.The co-infections were more prevalent in austral autumn / winter. The host-parasite relations and co-infections by nasal mites in C. ruficapillus were reported for the first time, contributing to the knowledge about nasal mites in Brazil.
\end{abstract}

KEYWORDS. Chestnut-capped blackbird, Boydaia, Sternostoma, Ptilonyssus.

RESUMO. Relações parasito-hospedeiro e co-infeç̧ão de ácaros nasais de Chrysomus ruficapillus (Passeriformes: Icteridae) no sul do Brasil. Cento e vinte e dois Chrysomus ruficapillus foram examinados no extremo sul do Brasil, a fim de pesquisar a presença de ácaros nasais e as relações hospedeiro-parasito. As infecções por ácaros nasais foram analisadas quanto a: presença de Ereynetidae e Rhinonyssidae considerando o total dos hospedeiros examinados; a maturidade sexual dos machos (juvenis e adultos); períodos de coleta das aves e presença de co-infecções. Foram identificados cinco taxa, quatro pertencentes à Rhinonyssidae (Sternostoma strandtmanni, Ptilonyssus sairae, P. icteridius and Ptilonyssus sp.) e um à Ereynetidae (Boydaia agelaii). Machos adultos foram parasitados por um taxa a mais do que os machos juvenis. Co-infecções ocorreram em 22 hospedeiros, entre dois, três e quatro taxa, pertencentes à Ereynetidae e Rhinonyssidae. As co-infecções foram mais prevalentes no outono/inverno austral. As relações hospedeiro-parasito e co-infecções por ácaros nasais em C. ruficapillus foram relatadas pela primeira vez, contribuindo para o conhecimento do hospedeiro e ampliando as informações sobre ácaros nasais no Brasil.

PALAVRAS-CHAVE. Garibaldi, Boydaia, Sternostoma, Ptilonyssus.

Mites (Arachnida: Acari) represent a very diversified group, with at least 2,500 described species allocated into 40 families (Proctor \& Owens, 2000). According to SKORACKI et al. (2012) it is estimated that the Prostigmata (Trombidiformes) bird parasites could be represented by 5,000 species, of which only $10 \%$ are described. These mites occupy different microhabitats in the host body, such as skin, feathers, intracutaneous layers and respiratory tract (SKoracki et al., 2012). The group includes the families Cheyletidae, Harpirhynchidae, Syringophilidae, Cloacaridae, and Ereynetidae (SKORACKI et al., 2012).

Mesostigmata includes Dermanyssidae, Laelapidae, Macronyssidae (parasites of nests, skin of the host or predators), Ascidae (phoretic mites, which are in hummingbird nostrils of Apodiformes: Trochilidae), and Rhinonyssidae (parasite nostrils and trachea) (РRoctor \& Owens, 2000). There are records of nasal mites for the most modern birds
(Neoaves) in every continent (Dimov, 2012). According to HYLAND (1979), the evolution of mites generally follows the one of their hosts.

Rhinonyssidae and Ereynetidae are parasites that inhabit the respiratory system of birds, besides being bloodsucking and consumers of tissue, respectively. Ereynetidae species are located in the innermost portion of the nasal cavity (drier environment) and are very agile because of the presence of setae in the body (HYLAND, 1979). Species of Rhinonyssidae are found embedded in the secretions of the cavity (higher humidity), they move slowly in the mucous membranes and cavities (FURMAN, 1957).

In addition, Rhinonyssidae is considered the most diverse taxon, distributed in eight genera. Species vary in its degree of host specificity, and, many are restricted to a single family of birds and others occur in hosts of different orders (PenCe, 1973a; 1975; SKoracki et al., 2012). 
Ereynetidae apparently are little pathogenic, as well as Rhinonyssidae, when in low intensities of infection (KNEe \& Proctor, 2010). About the biology and mode of transmission of nasal mites there is not much information in the literature, BrooKs \& StrandtMANN (1960) suggested that the transmission of Rhinonyssidae occurs quickly in the moment of feeding the juvenile birds or during the cohort when the two birds are closely associated, which would hinder the interspecific transmission.

Chrysomus ruficapillus (Vieillot, 1819) occurs in French Guiana, Brazil, Bolivia, Paraguay, Argentina and Uruguay (NAROSKY \& YZURIETA 2003; IUCN, 2016). It is a swamp species of Brazilian Pampa with gregarious habit and can be found in flocks ranging from a few birds until thousands, and is considered one of the most abundant birds of Rio Grande do Sul state (BeLton, 1994), being and closely linked to rice cultivation (Oryza spp.) (SiLVA, 2004).

The nasal mites previously registered at $C$. ruficapillus were Boydaia agelaii Fain \& Aitken, 1968 (Ereynetidae) from states of São Paulo and Rio Grande do Sul, Brazil (AMARAL \& ReBOUÇAS, 1974a; Bernardon et al., 2015), and the Rhinonyssidae: Ptilonyssus icteridius (Strandtmann \& Furman, 1956) in São Paulo (Amaral \& RebouÇAS, 1974a), and Sternostoma strandtmanni Furman, 1957, Ptilonyssus sairae Castro, 1948, Ptilonyssus sp. and P. icteridius in Rio Grande do Sul (BERnARDon et al., 2017).

The study of host-parasite relationships is essential to assist and understand the biology of both groups in these interactions. In this context, the parasitological indexes of the infections by Ereynetidae and Rhinonyssidae of $C$. ruficapillus in southern of Brazil are compared according to the periods of collect of hosts, the sexual maturity of the males, and the occurrence of co-infections.

\section{MATERIAL AND METHODS}

Collection of hosts. One hundred twenty-two hosts (20 females, 102 males: 46 adults and 56 juveniles) of Brazilian Pampa were examined from the municipality of Rio Grande, state of Rio Grande do Sul, Brazil ( $32^{\circ} 14^{\prime}$ 'S; $52^{\circ} 29^{\prime} \mathrm{W}$ ). The capture was performed in a farm (rice plantation) in "Granjas 4 Irmãos S. A.", where the trap (one cube with sized $2.5 \mathrm{~m}^{3}$ with metal edges, covered with screen and top opening, which allows the entry of birds but not their exit) was installed containing potable water and bird food ad libitum. The samples were collected in the months of December 2013, January, February, May, June and July 2014 (were collect 20 birds in each month and other two were added in the last sample).

The identification of birds was performed according to Betton (1994). The capture, euthanasia, and transport of birds were licensed by "Instituto Chico Mendes de Conservação da Biodiversidade" (ICMBio/41095-3) and approved by "Comissão de Ética em Experimentação Animal, Universidade Federal de Pelotas - UFPel" (CEEA/UFPel/1477). After euthanasia, the hosts were packed individually in plastic bags and transported to the "Laboratório de Parasitologia de
Animais Silvestres" (LAPASIL/UFPel), Departamento de Microbiologia e Parasitologia, Instituto de Biologia, UFPel and frozen until processing.

Collecting, preparing and identification of nasal mites. For mites collection, a cut was made in one nostril reaching (on the same side) to the external orifice of the ear, and then repeating the process on the opposite side. In order to form a right angle to the inferior portion, the turbinates were sectioned lengthwise, and then returned back to the top of the head (FAIN, 1956). Later on, the cavity was washed with water jet in a sieve opened mesh $(150 \mu \mathrm{m})$. The resulting content, the cavity and the respiratory tract were examined in stereomicroscope (Olympus ${ }^{\circledR} \mathrm{SZ}$ 61). Mites were preserved in alcohol 70\%, mounted between slides and coverslip with Hoyer's, photographed under an Olympus ${ }^{\circledR} \mathrm{BX} 41$ microscope with an attached camera system. Morphological identification was performed according to the dichotomous key of PenCe (1975). Vouchers were deposited in the "Coleção de Artrópodes do Laboratório de Parasitologia de Animais Silvestres" - CALAPASIL/UFPel (478 at 488 and 522 at 525) Departamento de Microbiologia e Parasitologia, Instituto de Biologia, UFPel.

Parasitological analyzes. The term "assembly" was used in this study according to the concept of FAUTH et al. (1996), because it represents the universe of species (taxonomic limits) and limits of distribution (geographic) according to the objectives of the study. This differs from the classic non-operational concept of community.

The assembly of nasal mites C. ruficapillus was analyzed using the following parameters: prevalence ( $\mathrm{P} \%)$, mean abundance of infection (MA), and mean intensity of infection (MII), according to Bush et al. (1997) and range of infection (R) according to BusH et al. (2001). Statistical analysis were performed using the "Quantitative Parasitology 3.0 Version 2.0" program (RózsA et al., 2000), for comparisons between the $\mathrm{P} \%(\mathrm{p}<0.05)$, using the Chisquare test $\left(\mathrm{X}^{2}\right)$ and MI confidence interval for the "bootstrap" $(\mathrm{BC} \alpha \mathrm{p}<0.05)$.

The infections by nasal mites were analyzed as: (a) the presence of Ereynetidae (E) and Rhinonyssidae (R) mites, when considering the total hosts examined $(n=122)$ to assess whether there are differences in the infections between the two groups of mites. Similarly, infections were compared only between species Rhinonyssidae and the total sample of host; (b) maturity sexual of males: juvenile males (JM) $(n=56)$ and adult males (AM) $(n=46)$, in order to check if there is any difference between infections nasal mites $(E+R)$, nasal mites Ereynetidae (E) and Rhinonyssidae mites (R). The females were collected in minor number $(\mathrm{n}=20$ birds) and have not been defined as the stage of development (adult or juvenile). Therefore, it was excluded for this analysis; (c) the collect periods: Collection period-I (CP-I, $n=60$ birds): December, January and February $=$ summer in the southern hemisphere; Collection period-II (CP-II, $n=62$ birds): May, June and July $=$ autumn $/$ winter in the southern hemisphere. With the aim of cheking for differences in infections nasal mites $(E+R)$ between periods; (d) the presence of co-infections (one host 
parasitized by at least two species of nasal mites) being a species of Ereynetidae and Rhinonyssidae (ExR) or species Rhinonyssidae $(\mathrm{RxR})$ considering the total hosts $(\mathrm{n}=122)$. In this context, it analyzed the $\mathrm{P} \%$ of co-infections to check for differences between the sampling periods (CP-I and CP-II).

\section{RESULTS}

From the 122 Chrysomus ruficapillus examined, $62.2 \%(76 / 122)$ were positive for nasal mites, $47.5 \%(58 / 122)$ for Ereynetidae (Prostigmata), and 27.9\% (34/122) for Rhinonyssidae (Mesostigmata). The assembly was composed by: Boydaia agelaii (Ereynetidae) (188 females and 33 larvae), Sternostoma strandtmanni (80 females, 1 male and 2 larvae), Ptilonyssus sairae (45 females), Ptilonyssus icteridius (54 females and 1 male), and Ptilonyssus sp. (2 females) morphologically distinct from the other two (Rhinonyssidae) (Figs 3-7). All mites were found in the nostril cavity (Figs 1, 2). However, pathological features were not evaluated.

The parasitological indexes $\mathrm{P} \%$, MA, MII and R, the total number of infected birds and host's gender are presented in Tab. I.

Boydaia agelaii was the nasal mite with the highest values of prevalence and abundance of infection $(\mathrm{P} \%=47.5$; $\mathrm{MA}=1.8$ ) (Tab. I). While the highest value of intensity of infection was from $S$. strandtmanni $(\mathrm{MII}=5.5)$ and the range was from P. icteridius $(\mathrm{R}=1-21)$ (Tab. I). Ereynetidae even represented by only one species, had the highest value of prevalence $(\mathrm{P} \%=47.5)(\mathrm{p}<0.05)$ when compared with Rhinonyssidae (Tab. II). Comparisons of $\mathrm{P} \%$ and MII between the taxa of Rhinonyssidae did not show differences (Tab. II). Boydaia agelaii, S. strandtmanni, P. sairae and P. icteridius were found in C. ruficapillus female, and males: adult and juveniles, however, Ptilonyssus sp. occurred only in male adults (Tab. I). The hosts male adults were parasitized by five taxa, while male juveniles by four (Tab. I). However, have not difference statistic (interfamily) in relation to $\mathrm{P} \%$ and MII of nasal mites between hosts adults and juveniles (Tab. III).

Regarding periods of host collection, the prevalence of nasal mites $(\mathrm{E}+\mathrm{R})$ was higher $(\mathrm{p}<0.05)$ in CP-II $(\mathrm{n}=62)$ $(\mathrm{P} \%=72.6)$, when compared to $\mathrm{CP}-\mathrm{I}(\mathrm{n}=60)$ which was equal to $\mathrm{P} \%=50$. There was no significant difference in the mean intensity of infection of mites, in CP-I (MII=4.3) and in CP-II (MII=5.9).

The occurrence of more than one species of mites in the same host (co-infection), was observed in 22 birds ( 3 females, 19 males: 4 adult and 15 juveniles) $(\mathrm{P} \%=18.0)$. Between ExR (29 times) and among RxR (21 times). The most frequent infection involving ExR was $B$. agelaii with $P$. sairae, and between RxR the most frequent relationship was
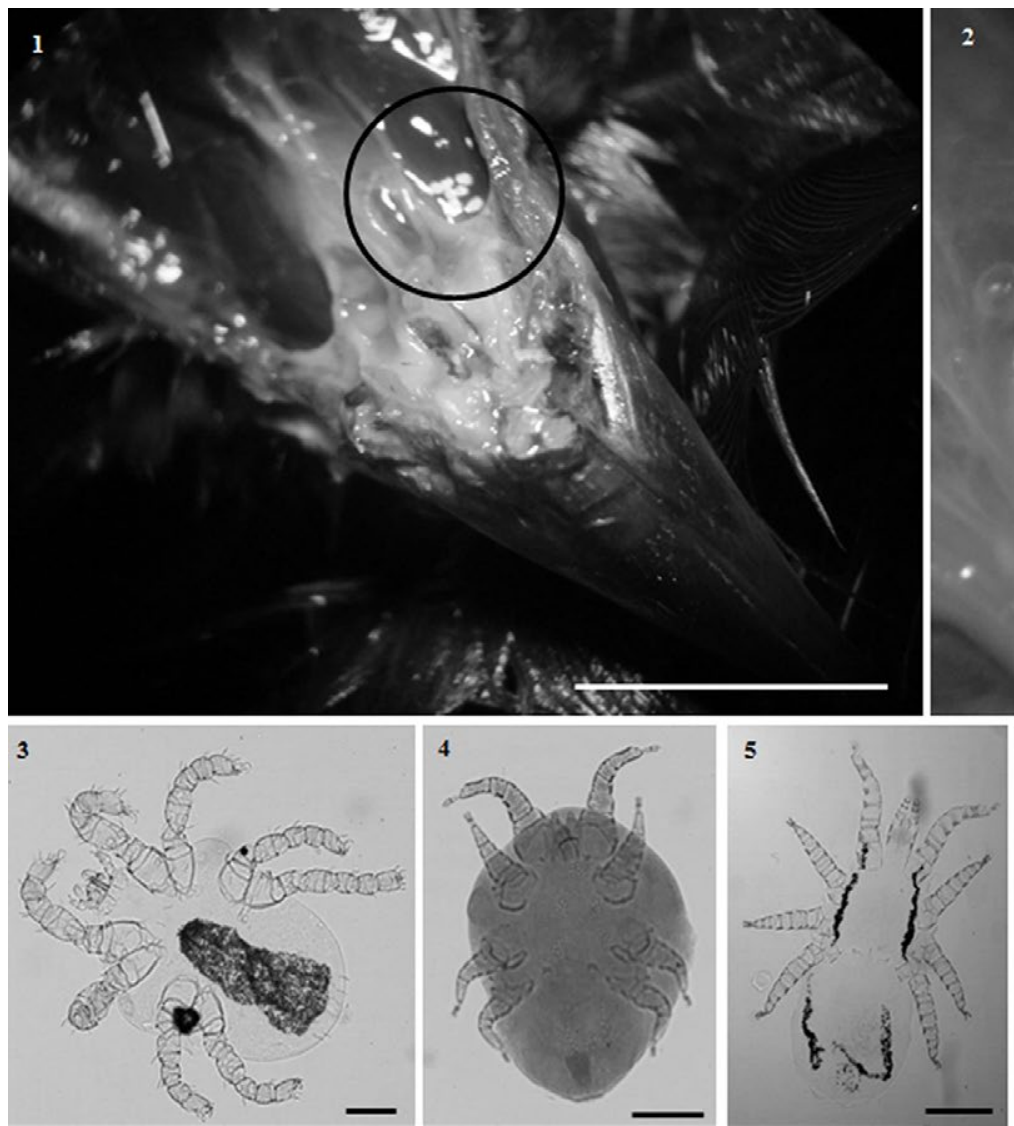

6
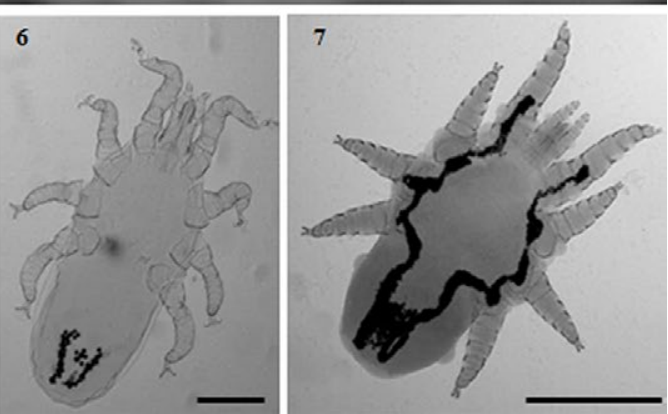

Figs 1-7. Nasal mites parasites of Chrysomus ruficapillus (Vieillot, 1819) (Passeriformes: Icteridae) from southern of Brazil: 1, cavity nasal parasitized, circle highlights the location of mites in the nasal turbinates $($ Bar $=80 \mathrm{~mm}) ; 2$, specimens of Ereynetidae and Rhinonyssidae $($ Bar $=30 \mathrm{~mm}) ; 3 ;$ Boydaia agelaii Fain \& Aitken, 1967 (Bar =0.09 mm); 4, Sternostoma strandtmanni Furman, 1957 (Bar = 0.12 mm); 5 , Ptilonyssus icteridius $($ Strandtmann \& Furman, 1956) $($ Bar $=0.14 \mathrm{~mm}) ; 6$, Ptilonyssus sairae Castro, $1948($ Bar $=0.15 \mathrm{~mm}) ; 7$, Ptilonyssus $\mathrm{sp}($ Bar $=0.2 \mathrm{~mm})$. 
Tab. I. Prevalence (P\%), mean abundance of infection (MA), mean intensity of infection (MII), and range (R) of nasal mites belonging to Ereynetidae and Rhinonyssidae of Chrysomus ruficapillus (Vieillot, 1819) $(\mathrm{n}=122)$ from southern of Brazil. Prevalence of nasal mites in female (F), adults male (AM) and juvenile male (JM). (NI= number of infected birds).

\begin{tabular}{|c|c|c|c|c|c|c|c|}
\hline \multirow{3}{*}{ Taxa Acari } & \multirow{2}{*}{\multicolumn{4}{|c|}{$\begin{array}{c}\text { All hosts } \\
\mathrm{F}+\mathrm{AM}+\mathrm{JM}(\mathrm{n}=122)\end{array}$}} & \multicolumn{3}{|c|}{ Host' gender } \\
\hline & & & & & \multirow{2}{*}{$\begin{array}{l}\mathrm{F}(\mathrm{n}=20) \\
\mathrm{P} \%(\mathrm{NI})\end{array}$} & \multirow{2}{*}{$\begin{array}{c}\mathrm{AM}(\mathrm{n}=46) \\
\mathrm{P} \%(\mathrm{NI})\end{array}$} & \multirow{2}{*}{$\begin{array}{c}\mathrm{JM}(\mathrm{n}=56 \\
\mathrm{P} \%(\mathrm{NI})\end{array}$} \\
\hline & $\mathrm{P} \%(\mathrm{NI})$ & MA & MII & $\mathrm{R}$ & & & \\
\hline EREYNETIDAE + RHINONYSSIDAE & $62.2(76)$ & - & - & - & - & - & - \\
\hline EREYNETIDAE & $47.5(58)$ & - & - & - & - & - & - \\
\hline Boydaia agelaii & $47.5(58)$ & 1.8 & 3.8 & $1-17$ & $7.4(9)$ & $16.4(20)$ & $23.8(29)$ \\
\hline RHINONYSSIDAE & $27.9(34)$ & - & - & - & - & - & - \\
\hline Sternostoma strandtmanni & $12.2(15)$ & 0.6 & 5.5 & $1-20$ & $3.3(4)$ & $2.4(3)$ & $6.5(8)$ \\
\hline Ptilonyssus sairae & $14.7(18)$ & 0.3 & 2.5 & $1-7$ & $2.4(3)$ & $1.6(2)$ & $10.6(13)$ \\
\hline Ptilonyssus icteridius & $13.9(17)$ & 0.4 & 3.2 & $1-21$ & $1.6(2)$ & $4.1(5)$ & $8.2(10)$ \\
\hline Ptilonyssus sp. & $1.6(2)$ & 0.01 & 1 & 1 & 0 & $1.6(2)$ & 0 \\
\hline
\end{tabular}

Tab. II. Comparasion of Prevalence (P\%) and mean intensity of infection (MII) between Ereynetidae X Rhinonyssidae, between Ptilonyssus spp. $\mathrm{X}$ Sternostoma strandtmann and between the species of Rhinonyssidae parasites of Chrysomus ruficapillus (Vieillot, 1819) ( $\mathrm{n}=122)$ from southern of Brazil. Different letter indicate significant differences $(\mathrm{p}<0.05)$; $\mathrm{NI}=$ number of infected birds.

\begin{tabular}{lcc}
\hline \multirow{2}{*}{ Taxa Acari } & \multicolumn{2}{c}{ Parasitological indexes } \\
\cline { 2 - 3 } & $\mathrm{P} \%(\mathrm{NI})$ & $\mathrm{MII}(\mathrm{NI})$ \\
\hline EREYNETIDAE & $47.5^{\mathrm{a}}(58)$ & 3.8 \\
RHINONYSSIDAE & $27.9^{\mathrm{b}}(34)$ & 5.4 \\
RHINONYSSIDAE & & \\
Ptilonyssus spp. & $19.7(24)$ & 4.2 \\
Sternostoma strandtmanni & $12.3(15)$ & 5.5 \\
Ptilonyssus saire & $14.8(18)$ & 2.5 \\
Ptilonyssus icteridius & $13.9(17)$ & 3.2 \\
Sternostoma strandtmanni & $12.3(15)$ & 5.5 \\
Ptilonyssus sp. & $1.6(2)$ & 1 \\
\hline
\end{tabular}

Tab. III. Comparasion of indexes parasitological (P\%) and mean infensity of infection (MII) of nasal mites Ereynetidae (E) and Rhinonyssidae (R) in adult males (AM) and juvenil males (JM) of Chrysomus ruficapillus (Vieillot, 1819) $(\mathrm{n}=122)$ from southern of Brazil ( $\mathrm{NI}=$ number of infected birds).

\begin{tabular}{|c|c|c|c|c|}
\hline \multirow{3}{*}{ Taxa Acari } & \multicolumn{4}{|c|}{ Sexual maturity of males } \\
\hline & \multicolumn{2}{|c|}{$\mathrm{AM}(\mathrm{n}=46)$} & \multicolumn{2}{|l|}{$\mathrm{JM}(\mathrm{n}=56)$} \\
\hline & $\mathrm{P} \%(\mathrm{NI})$ & MII & $\mathrm{P} \%(\mathrm{NI})$ & MII \\
\hline $\begin{array}{l}\text { EREYNETIDAE + } \\
\text { RHINONYSSIDAE }\end{array}$ & $56.5(26)$ & 6.0 & $62.5(35)$ & 4.2 \\
\hline EREYNETIDAE & $43.5(20)$ & 4.0 & $51.8(20)$ & 3.4 \\
\hline RHINONYSSIDAE & $19.1(9)$ & 3.4 & $32.1(18)$ & 6.1 \\
\hline
\end{tabular}

between $P$. icteridius and P. sairae. Co-infections involving taxa exclusively ExR were observed in 7 hosts ( 1 female, 6 males: 1 adult and 5 juveniles), while taxa exclusively Rhinonyssidae in 5 hosts ( 1 female, 4 males: 2 adult and 2 juveniles) (Tab. IV). These co-infections (ExR or RxR) occurred between two taxa of mites (11 hosts), between three taxa (9 hosts), and between four taxa (2 hosts) (Tab. IV).

\section{DISCUSSION}

Most studies of nasal mites has taxonomic character and consist in descriptions and re-descriptions species, construction of identification keys and researches of nasal mites in wildlife largely realized in North America (PENCE, 1973a,b, 1975; SPICER, 1987; KNEE \& Proctor, 2006, 2010; KNEE et al., 2008). Others were realized in Cuba (CERNY \& DusbabeK, 1970), Australia (Domrow, 1978; Proctor \& Owens, 2000), Russia (Dimov \& Mascarenhas, 2012), and Brazil (Amaral \& Rebouças, 1974a; Mascarenhas et al., 2009, 2011; CoIMBRA et al., 2012; BERNARDON et al., 2013, 2015, 2017; Mendes et al., 2014 and Sinkoc et al., 2016. In recent decades, complementary studies on phylogenetic relationships that use molecular techniques have been developed (RoJAs et al., 2001, 2002; MoRELLI \& SPICER, 2007) while studies that analyze the infections by nasal mites in the host, such as the one performed in this study with Passeriformes, are little discussed.

Researches available with species of Rhinonyssidae generally reported high diversity of hosts and small sample size of the same species of bird (PENCE, 1973b; Domrow, 1978; Amaral \& RebouÇas, 1974a; SPICER, 1987) reflecting, possibly, the low prevalence rates $(\mathrm{P} \%)$ recorded by the authors. In North America, to examine 1,927 birds, SPICER (1987) recorded $\mathrm{P} \%=17.3$ examined 502 hosts, and KNEE et al. (2008) reported $\mathrm{P} \%=15$ when analyzed 450 birds. On the other hand, in the present work the prevalence values of nasal mites in C. ruficapillus were higher $(\mathrm{P} \%=62.3)(76 / 122)$ (Ereynetidae + Rhinonyssidae) and P\% $=27.9$ (34/122) (Rhinonyssidae) than those presented by Pence (1973b), SPICER (1987) and KNEE et al. (2008), when analized 122 birds of the same species and locality, possibly reflecting in the results of $\mathrm{P} \%$.

Studies relating differences in the assembly composition of nasal mites, and on the development stage of the birds were approached by Porter \& STRANDTMANN (1952), Terbush (1963) and AMERSON (1967), without statistical tests.

Porter \& Strandtmann (1952) found higher prevalence values in adult birds $(\mathrm{P} \%=70)$ compared to the juveniles $(\mathrm{P} \%=40)$ when examining Passer domesticus (Linnaeus, 1758) (Passeriformes: Passeridae) parasitized by Ptilonyssus spp. In the same way, Terbush (1963) identified Larinyssus orbicularis Strandtmann, 1948 (Rhinonyssidae) in Larus argentatus Pontoppidan, 1763 (Charadriiformes: Laridae) found higher prevalence values in adults $(\mathrm{P} \%=55)$ 
Tab. IV. Co-infection of nasal mites Boydaia agelaii Fain \& Aitken, 1967 (Ereynetidae), Sternostoma strandtmanni Furman, 1957, Ptilonyssus sairae Castro, 1948, Ptilonyssus icteridius (Strandtmann \& Furman, 1956) and Ptilonyssus sp. (Rhinonyssidae). Between two taxa of nasal mites (total 11), three taxa (total 9) and four taxa (total 2) according to individual of Chrysomus ruficapillus (Vieillot, 1819) (n=122) from southern of Brazil [CR, C. ruficapillus; HG, host's gender; F, female; AM, adult male; JM, juvenile male; n, number of specimens of mites].

\begin{tabular}{|c|c|c|c|c|c|c|c|c|}
\hline Host & HG & Mite (n) & & Mite (n) & & Mite (n) & & Mite (n) \\
\hline CR 05 & $\mathrm{AM}$ & B. agelaii (1) & $\mathrm{X}$ & P. sairae (1) & & - & & - \\
\hline CR 35 & $\mathrm{JM}$ & B. agelaii (1) & $\mathrm{X}$ & P. sairae (2) & & - & & - \\
\hline CR 41 & $\mathrm{AM}$ & P. icteridius (13) & $\mathrm{X}$ & Ptilonyssus sp. (1) & & - & & - \\
\hline CR 57 & $\mathrm{JM}$ & S. strandtmanni (16) & $\mathrm{X}$ & P. sairae (3) & & - & & - \\
\hline CR 76 & $\mathrm{~F}$ & B. agelaii (10) & $\mathrm{X}$ & P. sairae (1) & & - & & - \\
\hline CR 82 & $\mathrm{JM}$ & B. agelaii (1) & $\mathrm{X}$ & P. sairae (1) & & - & & - \\
\hline CR 86 & $\mathrm{~F}$ & P. icteridius (1) & $\mathrm{X}$ & P. sairae (1) & & - & & - \\
\hline CR 108 & $\mathrm{JM}$ & B. agelaii (3) & $\mathrm{X}$ & P. sairae (6) & & - & & - \\
\hline CR 112 & $\mathrm{JM}$ & B. agelaii (17) & $\mathrm{X}$ & S. strandtmanni (3) & & - & & - \\
\hline CR 118 & $\mathrm{AM}$ & P. icteridius (2) & $\mathrm{X}$ & P. sairae (1) & & - & & - \\
\hline CR 121 & $\mathrm{AM}$ & B. agelaii (3) & $\mathrm{X}$ & P. icteridius (2) & & - & & - \\
\hline CR 91 & $\mathrm{JM}$ & B. agelaii (1) & $\mathrm{X}$ & P. sairae (1) & $\mathrm{X}$ & P. icteridius (1) & & - \\
\hline CR 93 & $\mathrm{JM}$ & B. agelaii (2) & $\mathrm{X}$ & P. sairae (1) & $\mathrm{X}$ & P. icteridius (2) & & - \\
\hline CR 96 & $\mathrm{AM}$ & B. agelaii (2) & $\mathrm{X}$ & P. icteridius (1) & $\mathrm{X}$ & Ptilonyssus sp. (1) & & - \\
\hline CR 102 & $\mathrm{JM}$ & P. icteridius (3) & $\mathrm{X}$ & P. sairae (7) & $\mathrm{X}$ & S. strandtmanni (5) & & - \\
\hline CR 105 & $\mathrm{~F}$ & B. agelaii (2) & $\mathrm{X}$ & P. sairae (6) & $\mathrm{X}$ & P. icteridius (1) & & - \\
\hline CR 107 & $\mathrm{JM}$ & B. agelaii (9) & $\mathrm{X}$ & P. sairae (2) & $\mathrm{X}$ & S. strandtmanni (6) & & - \\
\hline CR 115 & $\mathrm{JM}$ & B. agelaii (3) & $\mathrm{X}$ & P. sairae (1) & $\mathrm{X}$ & P. icteridius (21) & & - \\
\hline CR 116 & $\mathrm{JM}$ & B. agelaii (1) & $\mathrm{X}$ & P. sairae (5) & $\mathrm{X}$ & P. icteridius (1) & & - \\
\hline CR 117 & $\mathrm{JM}$ & B. agelaii (2) & $\mathrm{X}$ & P. sairae (4) & $\mathrm{X}$ & P. icteridius (1) & & - \\
\hline CR 89 & JM & B. agelaii (1) & $\mathrm{X}$ & P. sairae (1) & $\mathrm{X}$ & P. icteridius (2) & $\mathrm{X}$ & S. strandtmanni (9) \\
\hline CR 103 & $\mathrm{JM}$ & B. agelaii (2) & $\mathrm{X}$ & P. sairae (1) & $\mathrm{X}$ & P. icteridius (1) & $\mathrm{X}$ & S. strandtmanni (2) \\
\hline
\end{tabular}

than the immatures $(\mathrm{P} \%=37)$, in the first $(\mathrm{P} \%=1)$ and second year of life $(\mathrm{P} \%=40)$. AMERSON (1967) found similar results regarding Sternostoma and Larinyssus (Rhinonyssidae) infecting juveniles and adults of Onychoprion fuscata (=Sterna fuscata) Linnaeus, 1766 (Charadriformes: Laridae) $(n=460)$. The values of prevalence were higher from the 5th month of bird life $(\mathrm{P} \%=29.0)$ compared to the first four months (AMERSON, 1967). These authors suggest, that the probability of infection is greater over on the longevity of the host, increasing the likelihood of becoming infected as a function of exposure time, as for example, through with the cohort in between male and female, which may realize along its life. On the other hand, nasal mite infections (E $+\mathrm{R}$ ) in C. ruficapillus presented opposite results to those found by Porter \& StrandtMANn (1952), TERBUSH (1963) and AMERSON (1967), since juveniles males present $\mathrm{P} \%$ values higher $(\mathrm{P} \%=62.5)$ than adult males $(\mathrm{P} \%=56.5)$, even without statistical difference.

Cases of co-infection between Rhinonyssidae species are more frequently recorded than between species Ereynetidae and Rhinonyssidae. PENCE (1973b) reported the presence of more than one species of Rhinonyssidae, but did not indicate frequency. SPICER (1987) analyzed 103 birds (belonging to 11 orders), found a case of Ptilonyssus tyrannus Brooks \& Strandtmann, 1960 and Sternostoma pencei Spicer, 1984 in Empidonax Cabanis, 1855 (Passeriformes: Tyraniidae) $(\mathrm{n}=1)$, considered the infrequent relation, representing $1 \%$ of the total parasitized birds and $0.2 \%$ of the birds examined. Butenko \& Stanyikovich (1999) reported co-infection by Rhinonyssidae $\mathrm{P} \%=0.3$ in Anas platyrhynchos Linnaeus, 1758 (Anseriformes: Anatidae). KNEE et al. (2008) commented that there are rare cases in which a host is parasitized by more than one species of Rhinonyssidae and cases of two species of mites belonging to the same genus are very rare. Reported Tinaminyssus melloi (Castro, 1948) and Tinaminyssus columbae (Crossley, 1950) in Columba livia Gmelin, 1789 (Columbiformes: Columbidae); Ptilonyssus morofskyi Hyland, 1962 and Ptilonyssus nivalis Knee, 2008 in Plectrophenax nivalis (Linnaeus, 1758) (Passeriformes: Fringilidae); Ptilonyssus callinectoides (Brooks \& Strandtmann, 1960) and P. icteridius in Myiarchus crinitus (Linnaeus, 1758) (Passeriformes: Tyraniidae), and Sternostoma longisetosae (Hyland, 1961) and Ptilonyssus sp. in Tyrannus tyrannus (Linnaeus, 1766) (Passeriformes: Tyraniidae), corresponding to $3.5 \%$ of 114 birds examined (KNeE et al., 2008). Dimov \& Mascarenhas (2012) reported to Brazil Ptilonyssus sp. and Sternostoma sp. in: Lanio cucullatus (Statius Muller, 1776) $(\mathrm{n}=3)$ (one infected bird) $(\mathrm{P} \%=33.3)$; Saltator aurantiirostris Vieillot, 1817 (one infected bird) $(\mathrm{P} \%=12.5)$ and Paroaria coronata $(\mathrm{n}=28)$ (one infected bird) $(\mathrm{P} \%=3.5)$ (Passeriformes: Thraupidae) corresponding in total to $\mathrm{P} \%=3.8$ of the 39 birds examined. In Russia, they recorded Ptilonyssus sp. and Sternostoma sp. in Parus major Linnaeus, 1758 (Passeriformes: Paridae) $(\mathrm{n}=46)$ (one infected bird) $(\mathrm{P} \%=2.17)$. 
Co-infections involving Rhinonyssidae and Ereynetidae were presented by Knee et al. (2008) in North America and Dimov \& Mascarenhas (2012) in Brazil and Russia. KNEE et al. (2008) reported Rhinoecius brikinboricus Butenko, 1976 and Neoboydaia colymbiformi (Clark, 1964) in Asio otus (Linnaeus, 1758) (Strigiformes: Strigidae) $(\mathrm{n}=3)$. Dimov \& MASCARENHAS (2012) recorded Ptilonyssus sp. and Boydaia sp. $(\mathrm{P}=50), \mathrm{P}$. major $(\mathrm{n}=46)$ (one infected bird) $(\mathrm{P} \%$ $=6.2$ ) and in Passer montanus Linnaeus, 1758 (Passeriformes: Passeridae) $(\mathrm{n}=8)$ (an infected bird) $(\mathrm{P} \%=12.5)$ representing $\mathrm{P} \%=5.06$ of the 79 birds analyzed.

Co-infections with nasal mites apparently occur at low prevalence rates, according to SPICER (1987), BUTENKO \& Stanyikovich (1999) and KNeE et al. (2008). However, the authors examined a great diversity of hosts (orders / families / bird species) and low sample numbers of the same species. Therefore, the sample number should be considered as an important factor in future studies aimed at evaluating this relationship, either between species of Rhinonyssidae, or between species of Rhinonyssidae and Ereynetidae that parasitize Passeriformes, and probably other groups of birds. In this sense, the co-infections observed in C. ruficapillus $(\mathrm{P} \%=18.03)$, reinforce that the sample number (same host species) may be an important factor in the results with nasal mites. It should also be pointed out that aspects related to biology of bird, and also to biology of the species of mites should be considered.

In relation to the co-infections in the collection periods, the highest prevalence found in the collection period-II $(\mathrm{P} \%=81,8)(18 / 22$ occurrences), may be related to the behavior of the bird, because this period corresponds to winter in the southern hemisphere, characterized by low temperatures 10 $25^{\circ}$ (average of the last 30 years) (Fritzsons et al., 2015). This fact causes birds to pool up in the vegetation near to the field and road, which may facilitate contact between hosts, favoring so the transmission of mites. However, little is known about the biology and transmission of these species of mites and reproductive factors of mites should be studied. Therefore, additional studies on the behavior of C. ruficapillus should be conducted to aid in the understanding of parasitehost relationships and to evaluate possible forms of mite transmission among hosts.

In the study of host-parasite relationships, it is essential to consider the different taxonomic groups of birds, the peculiarities of behavior and evolutionary history, in addition to different geographical regions involved, both for the taxa of mites as of the hosts. SPICER (1987) comments that these factors are important and therefore may influence the prevalence of nasal mites. Thus, considering such factors, comparisons should be made with caution.

Boydaia agelaii was the only Ereynetidae found parasitizing C. ruficapillus. Cases of co-infections between Ereynetidae and Rhinonyssidae taxa have been reported. Adult males were parasitized for a higher rate than juvenile males. Co-infections by nasal mites were more prevalent in the collection period-II (austral autumn /winter in southern hemisphere). The most prevalent co-infection was between $B$. agelaii (Ereynetidae) and Ptilonyssus sairae (Rhinonyssidae). And the maximum number of taxa co-infecting $C$. ruficapillus was four species: B. agelaii, $P$. sairae, $P$. icteridius and $S$. strandtmanni.

The relationship of parasite-host, and co-infection by nasal mites in Chrysomus ruficapillus were reported for the first time, contributing to the knowledge parasitological of the host and enlarge the information about nasal mites in Brazil.

Acknowledgments. We thank the "Instituto Chico Mendes de Conservação da Biodiversidade" (ICMBio) for authorizing the collection of hosts and especially to "Granjas 4 Irmãos S.A" for their assistance throughout the project. And the "Coordenação de Aperfeiçoamento do Pessoal de Nível Superior" (CAPES) for scholarship support of the doctoral studies of the first author and for the financial support provided through refer edict 2010/032/CAPES.

\section{REFERENCES}

Amaral,V. \& RebouÇAS, M. M. 1974a. Notas sobre ácaros rinonissídeos de aves brasileiras (Mesostigmata: Rhinonyssidae). O Biológico 40:52-56.

Amaral, V. \& RebouÇAs, M. M. 1974b. Métodos para o estudo de ácaros Rinonissídeos. São Paulo, Instituto Biológico de São Paulo. 31p.

Amerson JR., A. B. 1967. Incidence and transfer of Rhinonyssidae (Acarina: Mesostigmata) in sooty terns (Sterna fuscata). Journal of Medical Entomology 4(2):197-199.

Belton, W. 1994. Aves do Rio Grande do Sul: Distribuição e biologia. São Leopoldo, UNISINOS. 548p.

Bernardon, F. F.; Müller, G. \& Mascarenhas, C. S. 2013. Rhinonyssidae (Acari: Gamasida) in Ardeidae (Aves: Pelicaniformes) in Brazil. Brazilian Journal of Biology 73:673-674.

Bernardon, F. F.; Müller, G. \& Mascarenhas, C. S. 2015. Ereynetidae (Acari: Prostigmata) in Chrysomus ruficapillus (Passeriformes: Icteridae) from Brazil. Revista Mexicana de Biodiversidad 86:829831.

Bernardon, F. F.; Müller, G. \& Mascarenhas, C. S. 2017. Rhinonyssidae in Chrysomus ruficapillus (Vieillot, 1819) (Passeriformes: Icteridae) from southern Brazil. Comparative Parasitology 84(1):67-71.

Brooks, D. L. \& Strandtmann, R. W. 1960. The nasal mites (Acarina) of some west Texas flycatchers (Tyrannidae). The Journal of Parasitology 46:418-432.

Bush, A. O.; Lafferty, K.; Lotz, J. \& Shostak, A. 1997. Parasitology meets ecology on its own terms: Margolis et al. revisited. The Journal of Parasitology 83:575-583.

Bush, A. O; Fernandez, J. C.; Esch, G. W. \& Seed, J. R. 2001. Parasitism: the diversity e ecology of animal parasites. Cambridge University Press, Cambridge, UK, 159p.

Butenko, O. M. \& Stanyukovich, M. K. 1999. The distribution of rhinonyssid mites (Acari, Gamasida, Rhinonyssidae) in the nasal cavities of some anatid birds. Ekologiya 2:52-56.

Cerny, V. \& DusbábeK, F. 1970. The nasal mites of Cuban birds II. Ptilonyssidae and Rhinonyssidae (Acarina: Mesostigmata). Acarologia 12:479-491.

Coimbra, M. A. A.; Mascarenhas, C. S.; Müller, G. \& Brum, J. G. 2012. Phthiraptera and Gamasida Parasites of Columbina picui (Temminck) (Columbiformes: Columbidae) in the State of Rio Grande do Sul, Southern Brazil. Brazilian Journal of Biology 72:583-585.

Dimov, I. D. 2012. A new nasal mite of the genus Ptilonyssus (Rhinonyssidae) from Parus caeruleus (Passeriformes) from Russia. Journal of the Hellenic Veterinary Medical Society 63:48-52.

Dimov, I. \& Mascarenhas, C. S. 2012. Co-parasitism of mites in Passeriformes birds from northwest Russia and Southern Brazil. Journal of Science and Practice 1(1): 7-10.

Domrow, R. 1978. Three collections of Rhinonyssine nasal mites from Queensland birds. Acarologia 20:487-514. 
FAIN, A. 1956. Les acariens de la famille Epidermoptidae et Rhinonyssidae parasites des fosses nasals d'oiseaux au Ruanda-Urundi et au Congo Belge. Annales du Musee Royal du Congo Belge Tervuren 60:1-176.

Fauth, J. E.; Bernardo, J.; Camara, M.; Resetarits, W. J., Jr.; van Buskirk, J.; McCollum, S. A. 1996. Simplifying the Jargon of Community Ecology: A Conceptual Approach. The American Naturalist 147(2):282-286.

Fritzsons, E.; Wrege, M. S. \& Mantovani, L. E. 2015. Altitude e temperatura: estudo do gradiente térmico no Rio Grande do Sul. Revista Brasileira de Climatologia 16:108-119.

Furman, D. P. 1957. Revision of the genus Sternostoma Belese and Troussart (Acarina: Rhinonyssidae). Hilgardia 26(10):473-495.

HyLAND, K. E. 1979. Specificity and parallel host-parasite evolution in the Turbinoptidae, Cytoditidae and Ereynetidae living in the respiratory passages of birds. In: Rodriguez, J. G. ed. Recent Advances in Acarology. Michigan State University, V Congress of Acarology, p. 363-365.

IUCN. 2016. Red List of Threatened Species. Avaliable at $<$ http://www. iucnredlist.org $>$. Accessed on October, 2016.

Knee, W. \& Proctor, H. 2006. Keys to the Families and Genera of Blood and Tissue Feeding Mites Associated with Albertan Birds. Canadian Journal of Arthropod Identification 2:1-18.

Knee, W. \& Proctor, H. 2010. Interactive HTML-based Dichotomus Key to Female Rhinonyssidae (Mesostigmata) from Birds in Canada. Canadian Journal of Arthropod Identification 9:1-64.

Knee, W.; Proctor, H. \& Galloway, T. 2008. Survey of nasal mites (Rhinonyssidae, Ereynetidae and Turninoptidae) associated with birds in Alberta and Manitoba, Canada. The Canadian Entomologist 140:364-379.

Mascarenhas, C. S.; Brum, J. G.; Coimbra, M. A. A. \& Sinkoc, A. L. 2009. Novos hospedeiros para o ácaro nasal Rhinonyssus rhinolethrum (Trouessart) (Gamasida: Rhinonyssidae) no Brasil. Neotropical Entomology 38:695-696.

Mascarenhas, C. S.; Coimbra, M. A. A.; Müller, G. \& Brum, J. G. 2011. Nasal mites (Gamasida: Rhinonyssidae) of Paroaria coronata (Miller) (Passeriformes: Emberezidae). Neotropical Entomology 40:507-508.

Mendes, M. M.; Mascarenhas, C. S.; Sinkoc, A. L. \& Müller, G. 2014. Nasal mites of Tyrannidae (Aves) in Brazil. Brazilian Journal of Biology 74:480-482.

Morelli, M. \& Spicer, G. S. 2007. Coespeciation between the nasal mite Ptilonyssus sairae (Acari: Rhinonyssidae) and its birds hosts. Systematic \& Applied Acarology 12:179-188.
Narosky, T. \& Yzurieta, D. 2003. Aves da Argentina e Uruguay: Guia para la Identificación. 15ed. Buenos Aires, Vazquez Mazzini. 348p.

Pence, D. B. 1973a. The nasal mites of birds from Louisiana IX Synopsis. The Journal of Parasitology 59(5):881-892.

Pence, D. B. 1973b. The nasal mites of birds from Louisiana VIII. Additional records and description of a new species (Acarina: Dermanyssidae, Ereynetidae, Epidermoptidae, and Cytoditidae). The Journal of Parasitology 59(5):874-880.

Pence, D. B. 1975. Keys, Species and Host List, and Bibliography for Nasal Mites of North American Birds (Acarina: Rhinonyssidae, Turbinoptinae, Speleognathinae and Cytoditidae). Lubbock, Special Publications of the Texas Tech Press. 148p.

Porter, J. C. \& Strandtmann, R. W. 1952. Nasal mites of the English sparrow. Texas Journal of Science 4:393-399.

Proctor, H. C. \& Owens, I. 2000. Mites and birds: diversity, parasitism and coevolution. Trends in Ecology and Evolution 15:358-364.

Rojas, M. D.; Mora, J. M.; Ubeda, C.; Cutillas, M.; Navajas, D. C. \& Guevara, D. C. 2001. Phylogenetic Relationships in Rhinonyssid Mites (Acari: Rhinonyssidae) Based on Mitochondrial 16SrDNA Sequences. Experimental \& Applied Acarology 25:957-967.

Rojas, M. D.; Mora, J. M.; Ubeda, C.; Cutillas, M.; Navajas, D. C. \& Guevara, D. C. 2002. Phylogenetic relationships in rhinonyssid mites (Acari: Rhinonyssidae) based on ribosomal DNA sequences: insights for the discrimination of closely related species. Parasitology Research 88:675-681.

Rózsa, L.; Reiczigel, J. \& Majoros, G. 2000. Quantifying parasites in samples of hosts. The Journal of Parasitology 86:228-232.

Silva, J. J. C. 2004. O pássaro-preto e a cultura do arroz. In: Gomes, A. S. \& Magalhães JR, A. M. eds. Arroz irrigado no Sul do Brasil. Brasília, Embrapa Informação Tecnológica, p. 677-725.

Sinkoc, A. L.; Brum, J. G. W. \& Müller, G. 2016. Ocorrência de Rhinonyssus rhinolethrum (Trouessart, 1895) em marreca caneleira Dendrocygna bicolor (Vieillot, 1816) e marreca piadeira Dendrocygna viduata (Linnaeus, 1766) na região sul do Rio Grande do Sul, Brasil. Arquivos do Instituto Biológico 83:1-3.

SpICER, G. S. 1987. Prevalence and host-parasite list of some nasal mites from birds (Acarina: Rhinonyssidae, Speleognathidae). The Journal of Parasitology 73(2):259-264.

SkoraCKi, M.; ZabludovsKaya, S. A. \& BochKov, A. V. 2012. A review of Prostigmata (Acariformes: Trombidiformes) permanently associated with birds. Acarina 20:67-107.

Terbush, L. E. 1963. Incidence of nasal mites in different age classes of herring gulls (Larus argentatus). The Journal of Parasitology 49:525. 